\title{
Penerapan Model Pembelajaran Kooperatif Teknik Think Pair Square (TPS) untuk Meningkatkan Hasil Belajar Matematika Siswa Kelas XII IPS 2 SMA Negeri 1 Bangko Kabupaten Rokan Hilir
}

\author{
Halimah Tusaddiah \\ SMA Negeri 1 Bangko Kabupaten Rokan Hilir \\ Bagan Barat, Bangko, Rokan Hilir Regency, Riau 28912 \\ saddiah.halimah168@gmail.com
}

\begin{abstract}
This study aims to provide an overview that the application of the Think Pair and Square (TPSq) Cooperative Learning Model can improve student learning at probabilities subject in Class XII IPS2 SMAN 1 BANGKO Rokan downstream. This research is a classroom action research (CAR) which is carried out in 2 cycles. For learning outcomes in the first cycle, $37.5 \%$ of students reached the KKM and in the second cycle, $54.2 \%$ of students reached the KKM. The basic score of students who reach the KKM is $29.2 \%$. The basic score in this study is the daily test score on the previous subject, namely statistics. The conclusion obtained from this study is that the application of the Think Pair Square Cooperative Learning Model can improve student learning outcomes.
\end{abstract}

Keywords: Learning Outcomes, Cooperative Learning Model Think Pair Square Technique,

\begin{abstract}
Abstrak
Penelitian ini bertujuan untuk memberi gambaran bahwa Penerapan Model Pembelajaran Kooperatif Teknik Think Pair Square (TPSq) dapat meningkatkan hasil belajar siswa pada pokok bahasan Peluang di Kelas XII IPS2 SMAN 1 BANGKO Rokan hilir. Penelitian ini merupakan penelitian Tindakan kelas (PTK) yang dilaksanakan dalam 2 siklus. Untuk hasil belajar pada siklus I yaitu 37,5\% siswa yang mencapai KKM dan pada siklus II yaitu 54,2\% siswa yang mencapai KKM. Skor dasar siswa yang mencapai KKM 29,2\%. Skor Dasar pada penelitian ini adalah nilai ulangan harian pada pokok bahasan sebelumnya yaitu statistik. Kesimpulan yag diperoleh dari penelitian ini bahwa penerapan Model Pembelajaran Kooperatif Teknik Think Pair Square dapat meningkatkan hasil belajar siswa.
\end{abstract}

Kata kunci: Hasil Belajar, Model Pembelajaran Kooperatif Teknik Think Pair Square

Copyright (c) 2021 Halimah Tusaddiah

Corresponding author: Halimah Tusadiah

Email Address: saddiah.halimah168@gmail.com (Bagan Barat, Bangko, Rokan Hilir Regency, Riau 28912)

Received 26 June 2021, Accepted 29 June 2021, Published 29 June 2021

\section{PENDAHULUAN}

Kurikulum 2013 bertujuan untuk mempersiapkan manusia Indonesia agar memiliki kemampuan hidup sebagai pribadi dan warga negara yang beriman, produktif, kreatif, inovatif, dan afektif serta mampu berkontribusi pada kehidupan bermasyarakat, berbangsa, bernegara,dan peradaban dunia. Pernyataan tersebut merupakan keharusan agar kemampuan berpikir logis, sistematis, kritis dan kreatif serta kemampuan bekerja sama menjadi fokus dalam pendidikan matematika.

Matematika merupakan ilmu yang mendasari segala bidang ilmu, oleh karena itu sangat penting mempelajari matematika. Menurut Ibrahim (2012: 35) matematika merupakan ilmu universal yang mendasari perkembangan teknologi modern,yang memiliki peran penting dalam berbagai disiplin dan memajukan daya pikir manusia. 
Matematika sering menjadi acuan maju dan tidaknya pendidikan suatu negara. Namun, pada kenyataannya kemampuan pemecahan masalah matematika di Indonesia masih tergolong rendah. Hal ini dibuktikan dari hasil laporan Badan Penelitian dan Pengembangan (Balitbang) bahwa hasil evaluasi TIMSS (Trends in Student Achievement in Mathematics and Science) tahun 2011 prestasi belajar matematika di Indonesia berada di posisi 5 besar dari bawah yaitu peringkat 36 dari 40 negara dengan nilai 386. Sedangkan pada tahun 2015 pencapaian matematika siswa Indonesia berada pada peringkat 45 dari 50 negara dengan skor 397. Hal tersebut menunjukkan bahwa nilai matematika menurun dari tahun ke tahun.

Herman Hudoyo (1992:3) mengemukakan bahwa mempelajari matematika adalah berkaitan dengan mempelajari ide-ide atau konsep yang bersifat abstrak. Untuk mempelajarinya digunakan simbol-simbol agar ide-ide atau konsep-konsep tersebut dapat dikomunikasikan. Dengan banyaknya simbol-simbol yang digunakan mengakibatkan siswa bersifat negatif terhadap dan menganggap bahwa matematika merupakan pelajaran yang sulit dan menakutkan .

Kenyataan sekarang ini pelajaran matematika cenderung dipandang sebagai mata pelajaran yang "kurang diminati" atau "kalau bisa dihindari" oleh sebagian siswa. Mereka seharusnya menyadari bahwa aturan-aturan yang ada dalam matematika mengajarkan untuk dapat berfikir logis, rasional, kritis, cermat, efisien dan efektif. Kemampuan tersebut sangat dibutuhkan guna menyongsong era persaingan bebas. Oleh karena itu, kreatifitas seorang guru dalam mengajar matematika menjadi faktor penting agar matematika menjadi mata pelajaran yang menyenangkan dan menarik di dalam kelas. Kreatifitas bukanlah suatu bakat, tetapi bisa dipelajari dan harus dilatih. Hal yang harus dilakukan seorang guru antara lain dengan menerapkan metode yang sesuai dan berusaha menambah pengetahuan tentang materi matematika itu sendiri.

Di lapangan banyak guru yang menerapkan pembelajaran konvensional. Pada prosesnya guru menerangkan materi dengan metode ceramah, siswa mendengarkan kemudian mencatat hal yang dianggap penting. Sumber utama pada proses ini adalah penjelasan guru. Siswa hanya pasif mendengarkan uraian materi, menerima dan "menelaah" begitu saja ilmu atau informasi dari guru. Hal ini tentu berakibat informasi yang didapat kurang begitu melekat dan membekas pada diri siswa. Dengan langkah ini juga siswa cepat merasa bosan, jika perasaan ini terus bertambah tentu akan berdampak buruk bagi siswa misalnya minat siswa untuk belajar matematika akan turun dampak selanjutnya prestasi siswa akan turun.

Belajar matematika itu merupakan kegiatan mental yang tinggi, sehingga didalam mempelajari harus bertahap dan berurutan serta berdasarkan kepada pengalaman yang sudah diperoleh. Siswa yang benar-benar belajar dalam dirinya akan terjadi perubahan tingkah laku yang diperlihatkan dalam bentuk hasil belajar. Oleh karena itu, perlu dikembangkan suatu metode pembelajaran yang mampu meningkatkan keaktifan siswa dalam pembelajaran matematika sehingga pada akhirnya dapat meningkatkan hasil belajar siswa. 
Tujuan dari pembelajaran matematika adalah agar peserta didik memiliki kemampuan antara lain : 1) Memahami konsep matematika, menjelaskan keterkaitan antar konsep dan mengaplikasikan konsep atau algoritma secara luwes, akurat, efisien, dan tepat dalam pemecahan masalah; 2) Menggunakan penalaran pada pola dan sifat, melakukan manipulasi matematika dalam membuat generalisasi, menyusun bukti, atau menjelaskan gagasan dan pernyataan matematika; 3) Memecahkan masalah yang meliputi kemampuan memahami masalah, merancang model matematika, menyelesaikan model dan menafsirkan solusi yang diperoleh; 4) Mengkomunikasikan gagasan dengan simbol, tabel, diagram, atau media lain untuk memperjelas keadaan atau masalah; 5) Memiliki sikap menghargai kegunaan matematika dalam kehidupan, yaitu memiliki rasa ingin tahu, perhatian, dan minat dalam mempelajari matematika, serta sikap ulet dan percaya diri dalam pemecahan masalah (BSNP, 2006). Oleh karena itu, diharapkan siswa dapat memperoleh hasil belajar yang tinggi dalam belajar matematika. Hasil belajar yang diharapkan adalah hasil belajar yang mencapai kriteria ketuntasan minimum. Hal ini sesuai dengan ketentuan dari BSNP (2006) bahwa siswa dikatakan tuntas belajar matematika apabila nilai hasil belajar matematika siswa telah mencapai Kriteria Ketuntasan Minimum (KKM) yang ditetapkan sekolah.

Namun yang terjadi adalah masih rendahnya hasil belajar siswa, hal ini menunjukkan adanya kesenjangan antara harapan dan kenyataan. Berdasarkan data yang diperoleh hasil belajar kelas XII IPS2 SMAN1 Bangko hanya 6 dari 24 siswa atau 25\% siswa kelas XII IPS2 pada materi pokok statistika yang mencapai Kriteria Ketuntasan Minimum (KKM) yang ditetapkan sekolah yaitu 70. Hal ini menunjukkan bahwa masih banyak siswa kelas XII IPS2 yaitu 75\% siswa yang belum mencapai KKM.

Guru menjadi faktor penentu tingkat keberhasilan dalam pembelajaran di kelas. Guru merupakan pihak yang paling dominan dalam mengarahkan proses pembelajaran di dalam kelas. Ada beberapa peran guru selain bertugas sebagai fasilitator, memindahkan pengetahuan, dan menanamkan nilai-nilai positif, harus menjadi teladan yang baik, berkepribadian yang patut jadi tauladan dan disenangi dalam pergaulan. Karena prestasi belajar anak didik juga akan berpengaruh terhadap perubahan sikap karena membenci kepribadian guru, jadi disini kepribadian guru juga sangat berpengaruh pada prestasi siswa.

Berdasarkan hasil pengamatan peneliti terhadap proses pembelajaran matematika siswa kelas XII IPS2 di SMAN 1 Bangko pada semester ganjil tahun pelajaran 2019/2020, terlihat bahwa pada proses pembelajaran, guru kurang memotivasi dan apersepsi. Guru memulai pelajaran dengan menjelaskan materi pelajaran dan memberikan contoh soal. Selanjutnya, guru memberikan soal latihan kepada siswa. Guru berusaha melibatkan siswa dengan meminta siswa menuliskan jawaban soal latihan di papan tulis. Namun, hanya siswa berkemampuan tinggi yang aktif. Siswa juga mengalami kesulitan jika soal yang diberikan memiliki bentuk yang berbeda dengan contoh soal yang diberikan. Hal ini terjadi karena siswa kurang memahami konsep materi. 
Dalam pelaksanaannya, guru berusaha melakukan perbaikan-perbaikan berupa variasi proses kegiatan pembelajaran agar siswa menjadi lebih aktif, misalnya dengan mengupayakan dilaksanakannya diskusi kelompok. Guru membagi siswa dalam kelompok-kelompok berempat. Dalam setiap kelompok terdapat satu atau dua siswa yang dianggap pintar untuk membimbing teman lain dan siswa yang kurang paham dapat bertanya kepada temannya dalam kelompok tersebut dengan harapan setiap siswa dapat berpartisipasi aktif dalam proses pembelajaran. Namun yang terjadi adalah diskusi belum terlaksana dengan baik, dalam kelompok-kelompok tersebut hanya beberapa siswa saja yang aktif, sedangkan yang lainnya hanya menyalin pekerjaan temannya. Sehingga ketika diberikan ulangan, banyak siswa yang tidak bisa menyelesaikan soal yang diberikan.

Proses pembelajaran merupakan salah satu faktor yang mempengaruhi hasil belajar siswa. Proses pembelajaran yang optimal akan menghasilkan hasil belajar yang optimal pula. Keefektifan pengalaman (proses) belajar-mengajar berhubungan dengan pencapaian hasil belajar yang optimal (Sudjana, 2010). Proses belajar yang selama ini berpusat pada guru memiliki kelemahan menjadikan siswa pasif dan kurang memahami konsep. Untuk itu diperlukan suatu model pembelajaran yang dapat melibatkan siswa secara aktif dalam proses pembelajaran, sehingga akan mempermudah siswa dalam memahami konsep materi.

Proses pembelajaran untuk mencapai Kompetensi Dasar (KD) menurut Permendiknas RI nomor 41 tahun 2007 tentang standar proses untuk satuan pendidikan dasar dan menengah pelaksanaan pembelajaran meliputi kegiatan pendahuluan, kegiatan inti dan kegiatan penutup. Kegiatan pendahuluan ditujukan untuk membangkitkan motivasi dan memfokuskan perhatian peserta didik untuk berpartisipasi aktif dalam proses pembelajaran. Kegiatan inti merupakan proses pembelajaran untuk mencapai kompetensi dasar yang dilakukan secara interaktif, inspiratif, menyenangkan, menantang, memotivasi peserta didik untuk berpartisipasi aktif, serta memberikan ruang yang cukup bagi prakarsa, kreativitas, dan kemandirian sesuai dengan bakat, minat, dan perkembangan fisik serta psikologis peserta didik. Kegiatan ini dilakukan melalui proses eksplorasi, elaborasi, dan konfirmasi. Kegiatan penutup dilakukan guru bersama-sama dengan peserta didik membuat rangkuman atau kesimpulan, melakukan penilaian, memberikan umpan balik dan merencanakan kegiatan tindak lanjut (BSNP, 2007).

Dari uraian di atas, dapat disimpulkan bahwa terdapat permasalahan dalam proses pembelajaran matematika di kelas XII IPS2 SMA Negeri 1 Bangko yaitu kurang optimalnya partisipasi aktif siswa dalam proses pembelajaran, guru kurang melibatkan siswa dalam aktivitas belajar secara optimal seperti yang diamanatkan dalam Permendiknas RI Nomor 41 tahun 2007. Optimalnya hasil belajar siswa bergantung pada proses pembelajaran (Sudjana, 2010). Hasil belajar pada dasarnya merupakan akibat dari suatu proses belajar sehingga untuk memperoleh hasil belajar yang optimal maka proses pembelajaran juga harus optimal.

Sesuai dengan Standar Proses dalam Permendiknas No. 41 Tahun 2007, salah satu tugas guru dalam menyusun perencanaan proses pembelajaran adalah menyusun Rencana Pelaksanaan 
Penerapan Model Pembelajaran Kooperatif Teknik Think Pair Square (TPS) untuk Meningkatkan Hasil Belajar Matematika Siswa Kelas XII IPS 2 SMA Negeri 1 Bangko Kabupaten Rokan Hilir, Halimah Tusaddiah

Pembelajaran (RPP). Dalam penyusunan RPP tersebut, guru memilih dan memodifikasi metode pembelajaran untuk mewujudkan suasana belajar yang menyenangkan, interaktif, inspiratif, menantang, dan memotivasi siswa untuk berpartisipasi aktif selama proses pembelajaran. Pemilihan model atau metode pembelajaran harus disesuaikan dengan situasi dan kondisi siswa serta karakteristik dari setiap indikator dan kompetensi yang hendak dicapai. Proses pembelajaran juga perlu direncanakan, dilaksanakan, dinilai, dan diawasi agar terlaksana secara efektif dan efisien.

Menanggapi permasalahan di SMAN 1 Bangko terhadap pembelajaran matematika, maka pembelajaran matematika di sekolah khususnya kelas XII IPS2 perlu suatu model pembelajaran yang sesuai untuk mengatasi masalah tersebut. Suatu model pembelajaran yang dapat mengoptimalkan partisipasi siswa dalam proses pembelajaran serta dapat membantu siswa dalam memahami materi pelajaran guna meningkatkan hasil belajar siswa. Usaha ini dimulai dengan pembenahan proses pembelajaran yang dilaksanakan guru, yaitu dengan menawarkan suatu model pembelajaran yang dapat meningkatkan hasil belajar sekaligus aktivitas siswa. Salah satunya yaitu dengan menawarkan model pembelajaran kooperatif teknik Think Pair Square (TPS).

Model Pembelajaran Think Pair Square merupakan modifikasi dari model pembelajaran kooperatif think pair share yang dikembangkan oleh Spencer Kangan tahun 1933. Model pembelajaran kooperatif teknik TPS memberi kesempatan kepada siswa untuk mendiskusikan ide-ide mereka dan memberikan suatu pengertian bekerja sendiri serta bekerja sama dengan orang lain. Pada langkah pertama siswa bekerja secara individu agar setiap siswa mengetahui kemampuannya masingmasing, kemudian siswa berdiskusi secara berpasangan sehingga setiap siswa dapat berpartisipasi aktif dalam proses pembelajaran, setelah itu masing-masing pasangan kembali pada kelompok berempat untuk melanjutkan diskusi dengan harapan setiap siswa dapat memahami materi pelajaran dengan lebih jelas. Keunggulan dari teknik ini adalah optimalisasi partisipasi siswa.

\section{METODE}

\section{Tempat dan Waktu Penelitian}

Penelitian ini dilaksanakan di kelas XII IPS2 SMAN 1 Bangko Kabupaten Rokan Hilir pada semester Ganjil tahun pelajaran 2019/2020 mulai September 2019 sampai dengan Oktober 2019

\section{Design Penelitian}

Bentuk penelitian ini adalah Penelitian Tindakan Kelas (PTK). Penelitian tindakan kelas adalah penelitian yang dilakukan oleh guru di kelasnya sendiri dengan cara (1) merencanakan; (2) melaksanakan; dan (3) merefleksikan tindakan secara kolaboratif dan partisipatif dengan tujuan memperbaiki kinerjanya sebagai guru, sehingga hasil belajar siswa dapat meningkat (Kusumah, Arikunto, 2009). Penelitian ini dilakukan secara kolaboratif, yaitu peneliti dan guru bekerjasama dalam proses pelaksanaan tindakan. Pelaksanaan tindakan oleh peneliti sendiri dan guru sebagai pengamat selama proses pembelajaran. 
Penelitian tindakan kelas adalah penelitian yang dilakukan oleh guru di kelas tempat ia mengajar yang bertujuan memperbaiki dan meningkatkan kualitas dan kuantitas proses pembelajaran (Iskandar, 2009). Dari tujuan penelitian tindakan kelas dan keinginan peneliti untuk memperbaiki proses pembelajaran, maka pada rencana penelitian ini peneliti menetapkan tindakan yang akan dilakukan adalah penerapan model pembelajaran kooperatif teknik TPS untuk meningkatkan hasil belajar siswa kelas XII IPS2 SMAN 1 Bangko.

Sebelum melaksanakan penelitian tindakan kelas, peneliti melakukan refleksi awal. Hasil refleksi awal pada penelitian ini sebagaimana telah dikemukakan dalam latar belakang yaitu proses pembelajaran berpusat pada guru sehingga siswa menjadi kurang aktif. Siswa tidak berupaya untuk membangun sendiri konsep materi yang diajarkan. Dalam diskusi yang dilaksanakan, siswa masih bekerja secara individu dan kurang bertanggungjawab atas kelompoknya. Sukarno (2009) menyatakan bahwa refleksi awal dilanjutkan dengan perencanaan tindakan perbaikan. Tindakan yang akan dilakukan dalam penelitian ini adalah penerapan Pembelajaran Kooperatif teknik Think Pair Square (TPS) untuk meningkatkan hasil belajar matematika siswa kelas XII IPS2 SMAN 1 Bangko Kabupaten Rokan Hilir pada materi pokok Peluang. Penelitian dilakukan secara kolaborasi antara peneliti dan guru. Peneliti akan bertindak sebagai guru, sedangkan guru bertindak sebagai pengamat selama proses pembelajaran berlangsung. Penelitian ini dilakukan sebanyak dua siklus. Siklus pertama terdiri atas tiga kali pertemuan dengan satu kali ulangan harian. Siklus kedua berlangsung selama empat kali pertemuan dengan satu kali ulangan harian. Setiap siklus melalui beberapa tahapan.

\section{Subjek Penelitian}

Subjek dalam penelitian ini adalah siswa kelas XII IPS2 SMAN 1 Bangko Kabupaten Rokan Hilir tahun pelajaran 2019/2020. Jumlah siswa dalam kelas tersebut adalah 24 orang yang terdiri dari 10 orang siswa laki-laki dan 14 orang siswa perempuan yang memiliki kemampuan tinggi, sedang, dan rendah.

\section{Teknik Pengumpulan Data}

\section{Teknik Observasi}

Teknik observasi dilakukan dengan menggunakan lembar pengamatan. Pengamatan dilakukan oleh guru matematika yang mengajar di kelas XII IPS2 SMAN 1 Bangko Kabupaten Rokan Hilir. Pengamatan dilakukan di setiap pertemuan. Pengamatan dilakukan dengan mengisi lembar pengamatan yang telah disediakan. Pengamatan yang dilakukan meliputi pengamatan tentang aktivitas guru dan aktivitas siswa selama proses pembelajaran.

\section{Teknik Tes}

Data hasil belajar siswa dikumpulkan melalui tes hasil belajar yang mencakup materi pokok Peluang. Tes hasil belajar dibuat berdasarkan indikator-indikator yang ingin dicapai pada materi pokok Peluang. Tes hasil belajar diberikan pada ulangan harian I dan ulangan harian II. Ulangan 
Penerapan Model Pembelajaran Kooperatif Teknik Think Pair Square (TPS) untuk Meningkatkan Hasil Belajar Matematika Siswa Kelas XII IPS 2 SMA Negeri 1 Bangko Kabupaten Rokan Hilir, Halimah Tusaddiah

harian I dilaksanakan pada siklus pertama setelah melalui tiga kali pertemuan. Ulangan harian II dilaksanakan pada siklus kedua setelah melalui empat kali pertemuan.

\section{HASIL DAN DISKUSI}

Kesesuaian antara langkah-langkah penerapan model pembelajaran kooperatif teknik Think Pair Square (TPS) yang direncanakan pada pelaksanaan tindakan dalam proses pembelajaran dapat dilihat dari lembar pengamatan setiap pertemuan. Kemudian data yang diperoleh melalui lembar pengamatan tersebut dianalisis.

\section{Siklus I}

Aktivitas siswa pada pertemuan pertama belum sesuai dengan perencanaan. Siswa masih pasif dalam mengikuti proses pembelajaran. Hal ini terjadi karena guru kurang komunikatif dalam memberikan motivasi dan apersepsi kepada siswa. Pada pertemuan selanjutnya, guru mulai melibatkan siswa secara aktif dalam memberikan motivasi dan melakukan apersepsi. Guru mengajukan pertanyaan-pertanyaan yang mengaitkan materi yang akan dipelajari dengan kehidupan sehari-hari dan mengingatkan siswa pada konsep-konsep materi yang telah dipelajari sebelumnya. Guru memberikan motivasi berupa penguatan verbal kepada siswa. Siswa mulai terlibat aktif dalam proses pembelajaran dan bersemangat dalam menjawab pertanyaan-pertanyaan yang diajukan guru.

Kegiatan siswa pada tahap think mengalami peningkatan pada setiap pertemuan. Pada pertemuan pertama, siswa masih belum memiliki kepercayaan diri untuk mengerjakan LKS secara individu.Siswa berusaha menyalin jawaban temannya. Guru memberikan jarak kursi antar siswa untuk meminimalisir kesempatan siswa menyalin jawaban teman. Pada tahap ini, guru memberikan bimbingan pada siswa yang mengalami kesulitan.Pada pertemuan berikutnya, beberapa siswa masih terlihat berusaha untuk menyalin jawaban teman, guru memberikan peringatan pada siswa tersebut.Selanjutnya, siswa mulai mengerjakan tugas individu dengan lebih baik.

Pada tahap pair, beberapa siswa masih belum melaksanakan diskusi berpasangan. Sebagian siswa hanya menyalin jawaban pasangannya. Pada pertemuan berikutnya, jumlah siswa yang hanya menyalin pekerjaan pasangannya semakin berkurang.Siswa mulai berdiskusi secara berpasangan dan saling membagikan pengetahuan. Guru memberikan bimbingan pada pasangan yang mengalami kesulitan. Kegiatan siswa pada tahap pair mengalami peningkatan pada setiap pertemuan.

Pada tahap square, siswa belum melaksanakan aktivitas diskusi berempat dengan baik.Sebagian siswa belum ikut serta dalam kegiatan diskusi berkelompok. Guru memberikan arahan agar siswa memiliki kesadaran untuk berpartisipasi dalam kegiatan diskusi kelompok. Pada pertemuan berikutnya, setiap siswa mulai aktif dalam kegiatan diskusi kelompok. Pada tahap ini, guru memberikan bimbingan pada kelompok yang mengalami kesulitan. Aktivitas siswa pada kegiatan diskusi berempat mengalami peningkatan pada setiap pertemuan. 
Presentasi yang dilakukan siswa semakin baik dalam setiap pertemuan.Pada pertemuan pertama, siswa enggan mempresentasikan hasil diskusi kelompok.Pada pertemuan berikutnya, siswa mulai memiliki kepercayaan diri untuk mempresentasikan hasil diskusi kelompoknya. Siswa juga mulai aktif menanggapi hasil preentasi kelompok lain. Demikian pula pada saat kegiatan menyimpulkan materi pelajaran.Siswa semakin aktif dalam mengajukan pendapat tentang kesimpulan materi yang dipelajari.

Guru melakukan upaya perbaikan dalam mengorganisasikan siswa sehingga waktu yang digunakan lebih efisien. Efektivitas bimbingan yang diberikan guru mengalami peningkatan pada setiap pertemuan.Pada pertemuan pertama, guru belum optimal dalam memberikan bimbingan pada siswa.Pada pertemuan berikutnya, guru berusaha mengoptimalkan bimbingan yang diberikan pada siswa sehingga kegiatan yang dilakukan dalam membimbing siswa semakin baik.

Aktivitas membimbing siswa dalam menyimpulkan materi yang telah dipelajari tidak terlaksana pada pertemuan pertama. Pada pertemuan berikutnya, guru menyampaikan kesimpulan secara umum tanpa melibatkan siswa. Hal ini terjadi karena guru belum mampu mengalokasikan waktu sesuai dengan perencanaan.Pada pertemuan selanjutnya, guru melakukan perbaikan pada alokasi waktu sehingga waktu yang digunakan sesuai dengan perencanaan dan semua aktivitas dapat terlaksana dengan baik.

\section{Siklus II}

Pada siklus kedua, guru berusaha memperbaiki kekurangan-kekurangan berdasarkan refleksi pada siklus pertama. Guru berusaha menggunakan bahasa yang komunikatif dalam memberikan motivasi dan apersepsi. Guru juga berusaha melibatkan siswa secara aktif dalam kegiatan awal pembelajaran. Guru memberikan motivasi berupa pujian secara verbal sehingga siswa lebih bersemangat dalam mengikuti kegiatan pembelajaran. Aktivitas yang dilaksanakan mengalami peningkatan pada setiap pertemuan dan sesuai dengan perencanaan.

Pada siklus kedua, siswa melaksanakan kegiatan think dengan semakin baik. Siswa telah memiliki kesadaran dan lebih percaya diri untuk mengerjakan LKS secara individu terlebih dahulu. Aktivitas siswa pada kegiatan think mengalami peningkatan pada setiap pertemuan. Pada tahap pair, siswa telah melaksanakan kegiatan diskusi berpasangan dengan baik. Siswa aktif mendiskusikan permasalahan dengan pasangan dan tidak hanya menyalin pekerjaan teman.Demikian pula pada kegiatan diskusi berempat, siswa telah melaksanakannya dengan baik.Setiap anggota kelompok terlibat aktif dalam kegiatan diskusi.Aktivitas siswa telah terlaksana dengan baik sesuai dengan perencanaan.

Presentasi yang dilakukan siswa terlaksana dengan baik. Siswa mulai berani mengajukan diri ketika guru meminta kesediaan kelompok untuk mempresentasikan jawaban di depan kelas. Siswa juga semakin kritis dalam menanggapi hasil presentasi kelompok lain. Demikian pula pada saat menyimpulkan materi pelajaran. Siswa aktif mengajukan pendapat tentang kesimpulan materi yang dipelajari.Aktivitas siswa telah terlaksana dengan baik dan sesuai dengan perencanaan. 
Pelaksanaan kegiatan membimbing siswa telah dilaksanakan dengan baik oleh guru.Guru juga telah mengalokasikan waktu dengan baik sehingga semua aktivitas guru dan siswa dapat terlaksana sesuai dengan perencanaan.

\section{Analisis Ketercapaian KKM}

Ketercapaian Kriteria Ketuntasan Minimum (KKM) pada materi peluang secara keseluruhan disajikan dalam tabel berikut:

Tabel 9. Persentase Ketercapaian KKM Siswa

\begin{tabular}{|l|c|c|c|}
\hline & Skor Dasar & Ulangan Harian I & Ulangan Harian II \\
\hline $\begin{array}{l}\text { Jumlah siswa yang } \\
\text { mencapai KKM }\end{array}$ & 8 & 11 & 16 \\
\hline Persentase (\%) & 28,57 & 39,28 & 57,14 \\
\hline
\end{tabular}

Berdasarkan tabel di atas terlihat bahwa terjadi peningkatan jumlah siswa yang mencapai KKM dari skor dasar ke ulangan harian I dan peningkatan jumlah siswa yang mencapai KKM dari ulangan harian I ke ulangan harian II.Dengan demikian tindakan dikatakan berhasil.

\section{Analisis Distribusi Frekuensi Hasil Belajar}

Untuk mengetahui peningkatan nilai hasil belajar siswa kelas XII IPS 2 SMAN 2 Bangko Kabupaten Rokan Hilir sebelum dan setelah tindakan dapat dilihat pada tabel daftar distribusi frekuensi berikut:

Tabel 10. Daftar Distribusi Frekuensi Hasil Belajar Siswa

\begin{tabular}{|c|c|c|c|}
\hline \multirow{2}{*}{ Interval } & \multicolumn{3}{|c|}{ Frekuensi Siswa } \\
\cline { 2 - 4 } & Skor Dasar & Nilai UH I & Nilai UH II \\
\hline $17-30$ & 8 & 5 & 0 \\
\hline $31-44$ & 3 & 8 & 1 \\
\hline $45-58$ & 6 & 2 & 10 \\
\hline $59-72$ & 4 & 4 & 3 \\
\hline $73-86$ & 3 & 3 & 3 \\
\hline $87-100$ & 0 & 2 & 7 \\
\hline$\sum \boldsymbol{f}$ & $\mathbf{2 4}$ & $\mathbf{2 4}$ & $\mathbf{2 4}$ \\
\hline
\end{tabular}

Berdasarkan tabel distribusi frekuensi tersebut, terlihat bahwa terjadi perubahan hasil belajar antara skor dasar, ulangan harian I, dan ulangan harian II.Dari skor dasar ke ulangan harian I, frekuensi siswa yang memperoleh nilai rendah (17-30) menurun. Frekuensi siswa yang memperoleh nilai tinggi (87-100) mengalami peningkatan.Artinya, terjadi peningkatan hasil belajar matematika siswa dari skor dasar ke ulangan harian I. Hal ini menunjukkan bahwa tindakan yang dilakukan pada penelitian ini memberikan pengaruh terhadap hasil belajar matematika siswa.

Dari tabel dapat dilihat juga perubahan distribusi frekuensi hasil belajar siswa mengalami perubahan dari ulangan harian I ke ulangan harian II.Jumlah siswa yang memperoleh nilai rendah (1730) menurun.Sedangkan jumlah siswa yang memperoleh nilai tinggi (87-100) mengalami peningkatan.Artinya, pelaksanaan tindakan pada siklus II tetap memberikan peningkatan hasil belajar 
matematika siswa. Sehingga dapat disimpulkan bahwa tindakan berhasil atau dengan kata lain penerapan model pembelajaran kooperatif teknik Think Pair Square (TPS) dapat meningkatkan hasil belajar matematika siswa kelas XII IPS2 SMAN 1 Bangko Kabupaten Rokan Hilir.

Artinya, pelaksanaan tindakan pada siklus II memberikan peningkatan hasil belajar matematika siswa. Sehingga dapat disimpulkan bahwa tindakan berhasil atau dengan kata lain penerapan model pembelajaran kooperatif teknik Think Pair Square (TPS) dapat meningkatkan hasil belajar matematika siswa kelas XII IPS2 SMAN 1 Bangko Kabupaten Rokan Hilir.

\section{Diskusi}

Berdasarkan hasil pengamatan aktivitas guru dan siswa dapat dikatakan bahwa penerapan model pembelajaran kooperatif teknik Think Pair Square (TPS) mengalami peningkatan pada setiap pertemuan,proses pembelajaran semakin membaik dan sesuai dengan rencana pelaksanaan pembelajaran. Aktivitas guru telah sesuai dengan perencanaan dan siswa juga sudah semakin terbiasa dengan model pembelajaran yang diterapkan guru.Siswa berpartisipasi aktif dalam diskusi kelompok. Siswa juga sudah mulai percaya diri untuk tampil di depan kelas.

Berdasarkan analisis nilai perkembangan siswa dan penghargaan kelompok, terlihat bahwa pada ulangan harian I ada 6 siswa yang menyumbangkan nilai perkembangan 20 dan 9 siswa yang menyumbangkan nilai perkembangan 30. Hal ini menunjukkan bahwa ada 15 siswa yang memperoleh nilai ulangan harian I lebih tinggi dari skor dasar.Sehingga penghargaan kelompok pada siklus I terdiri dari dua kelompok baik, tiga kelompok hebat, dan satu kelompok super. Pada ulangan harian II terdapat 6 siswa yang menyumbangkan nilai perkembangan 20 dan 14 siswa yang menyumbangkan nilai perkembangan 30. Hal ini menunjukkan bahwa ada 20 siswa yang memperoleh nilai ulangan harian II lebih tinggi dari ulangan harian I. Ini menunjukkan bahwa kerjasama kelompok semakin baik sehingga terjadi peningkatan jumlah siswa yang memperoleh nilai sama atau lebih tinggi dari skor dasar. Peningkatan ini mengakibatkan penghargaan kelompok juga meningkat. Pada siklus II, terdapat satu kelompok yang mendapat penghargaan sebagai kelompok baik, satu kelompok hebat dan empat kelompok super.

Berdasarkan ketercapaian KKM indikator, tidak semua siswa yang mencapai KKM untuk setiap indikator.Kesalahan-kesalahan yang dilakukan siswa antara lain adalah dalam menentukan rumus yang digunakan untuk menyelesaikan permasalahan yang diberikan, kesalahan dalam memahami soal, dan kesalahan melakukan perhitungan. Berdasarkan analisis ketercapaian KKM siswa, persentase jumlah siswa yang mencapai KKM mengalami peningkatan dari skor dasar ke ulangan harian I dan dari ulangan harian I ke ulangan harian II.Berdasarkan analisis distribusi frekuensi data hasil belajar, hasil belajar siswa juga mengalami peningkatan.Jumlah siswa yang memperoleh nilai rendah menurun dan jumlah siswa yang memperoleh nilai tinggi meningkat.

Penerapan model pembelajaran kooperatif teknik Think Pair Square (TPS) pada proses pembelajaran siswa kelas XII IPS2 SMAN 1 Bangko Kabupaten Rokan Hilir telah dapat memberikan dampak positif pada pelaksanaan proses pembelajaran di kelas tersebut. Siswa menjadi lebih aktif 
dalam kegiatan pembelajaran sehingga proses pembelajaran tidak lagi didominasi oleh guru. Siswa juga lebih termotivasi untuk membangun pengetahuannya dan berpartisipasi aktif dalam kegiatan diskusi kelompok sehingga siswa dapat lebih memahami konsep materi.Hal ini memberikan pengaruh terhadap hasil belajar siswa. Jadi, hasil analisis tindakan ini mendukung hipotesis tindakan yang diajukan yaitu penerapan model pembelajaran kooperatif teknik Think Pair Square (TPS) dapat meningkatkan hasil belajar matematika siswa kelas XII IPS2 SMAN 1 Bangko Kabupaten Rokan Hilir pada materi pokok Peluang semester ganjil tahun ajaran 2019/2020.

Pada pelaksanaan proses penelitian, terdapat beberapa kekurangan dalam penyajian LKS terutama pada LKS 3 dan LKS 4. Guru belum menyajikan langkah penemuan konsep dengan tepat dan rinci sehingga siswa mengalami kesulitan dalam menyimpulkan generalisasi penerapan aturan kombinasi pada penjabaran Binom Newton. Oleh karena itu, pada pertemuan ini guru mengalami kendala waktu karena banyak memberikan bimbingan pada siswa.Pada penyajian LKS 4, langkahlangkah untuk menentukan definisi kejadian belum jelas.Kekurangan juga terjadi pada penyajian LKS 1.Pada penerapan aturan perkalian, guru kurang memberikan penguatan dalam menanamkan konsep aturan perkalian dengan syarat tertentu sehingga pada saat diberikan soal ulangan harian banyak siswa yang melakukan kesalahan dalam menentukan penempatan objek pada penerapan aturan perkalian.

Pada pelaksanaan penelitian terdapat beberapa kendala, di antaranya dalam efisiensi waktu, pada pertemuan pertama siswa masih bingung dengan model pembelajaran yang diterapkan. Siswa juga kurang aktif mengikuti kegiatan pembelajaran.Kekurangan-kekurangan ini menjadi bahan perbaikan bagi guru untuk pertemuan berikutnya. Guru berusaha melibatkan siswa agar lebih aktif dan siswa juga mulai terbiasa dengan model pembelajaran yang diterapkan sehingga pada pertemuan berikutnya siswa lebih aktif dan antusias dalam mengikuti kegiatan pembelajaran. Selain itu, kurangnya efisiensi waktu juga mengakibatkan siswa tidak mempunyai cukup waktu untuk menyelesaikan soal latihan pada kegiatan akhir sehingga guru tidak dapat mengetahui tingkat pemahaman setiap siswa pada setiap pertemuan. Kendala lain adalah karena kegiatan pembelajaran dilaksanakan pada jam terakhir sehingga konsentrasi siswa sudah berkurang. Guru mengatasi kendala ini dengan berusaha membuat siswa tidak terlalu kaku dalam mengikuti kegiatan pembelajaran.

\section{KESIMPULAN}

Berdasarkan hasil penelitian dan pembahasan, dapat disimpulkan bahwa penerapan model pembelajaran kooperatif teknik Think Pair Square (TPS) dapat meningkatkan hasil belajar matematika siswa kelas XII IPS2 SMAN 1 Bangko Kabupaten Rokan Hilir pada materi pokok Peluang semester ganjil tahun pelajaran 2019/2020.

Memperhatikan pembahasan dan kesimpulan di atas, maka peneliti mengajukan beberapa saran yang berhubungan dengan penerapan model pembelajaran kooperatif teknik Think Pair Square (TPS) pada pembelajaran matematika, yaitu: 
1. Guru mengorganisir waktu dengan baik agar lebih efektif sehingga kegiatan evaluasi pada kegiatan akhir dapat terlaksana dengan baik, siswa mempunyai cukup waktu untuk mengerjakan soal latihan yang diberikan dan guru dapat mengumpulkan jawaban siswa sehingga guru dapat mengetahui tingkat pemahaman siswa terhadap materi pelajaran pada setiap pertemuan.

2. Agar penerapan model pembelajaran kooperatif teknik TPS dapat berlangsung dengan baik sesuai dengan perencanaan, maka sebaiknya guru menginformasikan setiap tahap dalam pelaksanaan model pembelajaran kooperatif teknik TPS dengan lebih jelas dan rinci lagi kepada siswa, agar siswa mengerti langkah-langkah yang harus mereka lakukan dalam setiap tahap kegiatan pembelajaran.

\section{UCAPAN TERIMA KASIH}

Terimakasih kami ucapkan kepada Bapak/Ibu Kepala Sekolah dan Guru-guru di SMA Negeri 1 BANGKO Kabupaten Rokan Hilir yang telah memberikan izin dan dukungan kepada peneliti dalam melaksanakan penelitian ini. Terimakasih kepada siswa yang telah ikut berpartisipasi dalam melaksanakan penelitian ini.

\section{REFERENSI}

Arikunto, dkk., 2009, Penelitian Tindakan Kelas, Bumi Aksara, Jakarta.

BSNP., 2006. Panduan Penyusunan Kurikulum Tingkat Satuan Pendidikan Jenjang Pendidikan Dasar dan Menengah, Depdiknas, Jakarta.

BSNP., 2007, Peraturan Menteri Pendidikan Nasional Republik Indonesia Nomor 41 Tahun 2007 tentang Standar Proses untuk Satuan Pendidikan Dasar dan Menengah, BSNP, Jakarta.

Dimyati dan Mudjiono., 2006, Belajar dan Pembelajaran, Rineka Cipta, Jakarta

Djamarah, S.B., 2002, Psikologi Belajar, Rineka Cipta, Jakarta

Ibrahim, Muslimin, Muhammad Nur., 2000. Pembelajaran Kooperatif, Universitas Negeri Surabaya, Surabaya.

Iskandar., 2009, Penelitian Tindakan Kelas, Gaung Persada Press, Ciputat.

Kusumah, Wijaya., 2009, Mengenal Penelitian Tindakan Kelas, PT. Indeks, Jakarta.

Sudjana, N., 2007, Penilaian Hasil Proses Belajar Mengajar, Remaja Rosdakarya, Bandung.

Sudjana, N., 2010, Penilaian Hasil Proses Belajar Mengajar, Remaja Rosdakarya, Bandung.

Sugiyono, 2008, Metode Penelitian Kuantitatif, Kualitatif, dan R\&D, Alfabeta, Bandung.

Sukarno., 2009, Penelitian Tindakan Kelas, Media Perkasa, Surakarta 